\title{
Anticancer activity of a trans-platinum(II) complex of 3-aminoflavone to ovarian cancer cells
}

\author{
Magdalena Orzechowska ${ }^{1}$, Małgorzata Fabijańska ${ }^{2}$, Justyn Ochockii ${ }^{2}$, Maciej Małecki ${ }^{1}$ \\ ${ }^{1}$ Department of Applied Pharmacy, Medical University of Warsaw, Poland \\ ${ }^{2}$ Department of Bioinorganic Chemistry, Medical University of Lodz, Poland
}

\begin{abstract}
Objectives: Cisplatin is a classical anticancer drug used in the treatment of ovarian cancer. Unfortunately, the treatment is associated with numerous adverse effects. Studies concerning new platinum derivatives with less organ toxicity are conducted. The aim of this study was to analyse the effect of a new trans-platinum(II) complex of 3-aminoflavone on the viability and mortality of the cells from OVCAR 3 and CAOV 3 ovarian cancer cell lines and on the expression of the selected genes involved in the process of apoptosis.

Material and methods: The viability of ovarian cancer cells and the cytotoxicity of a trans-platinum(II) complex of 3-aminoflavone: [trans- $\mathrm{Pt}(3-\mathrm{af})_{2} \mathrm{Cl}_{2}$ ), trans-bis-(3-aminoflavone) dichloridoplatinum(II)] and cisplatin were analysed using a spectrophotometric method with the use of MTT assay and LDH assay. BAX, BCL2, BIRC5 gene expression analysis on mRNA level was conducted with the use of Real-Time PCR method.

Results: It was observed that parallel to an increase in the concentration of the new complex compound and cisplatin there is a decrease in viability and an increase in mortality of ovarian cancer cells. As a result of exposure to the studied compound and cisplatin, an increased $B A X$ gene expression and decreased $B C L 2$ and $B I R C 5$ gene expression were observed in the studied ovarian cancer cell lines.

Conclusion: Trans-Pt(3-af) ${ }_{2} \mathrm{Cl}_{2}$ exhibits anticancer activity towards OVCAR 3 and CAOV 3 ovarian cancer cell lines. The studied complex compound can be considered as a potential anticancer drug.
\end{abstract}

Key words: trans-Pt(3-af) ${ }_{2} \mathrm{Cl}_{2}$, cisplatin, ovarian cancer, OVCAR 3, CAOV 3, viability, apoptosis

Ginekologia Polska 2017; 88, 2: 68-74

\section{INTRODUCTION}

In 1965 the publication in Nature of the results of a study directed by Rosenberg opened new perspectives of cisplatin (cis - diamminedichloridoplatinum(II), CDDP) use in anticancer treatment [1]. In that study a chemotherapeutic potential of cisplatin was described. Rosenberg et al. investigated how microorganisms ( $E$. coli bacteria) behave under the influence of electric current. Thus the scientists proved that platinum electrodes used during the studies caused the death of cancer cells. Its mechanism of action relies on binding to DNA via N7 guanine and adenosine atoms [2, 3]. The 1.2 intrastrand crosslinks are responsible for the activity of platinum complexes. Cisplatin is widely used in the anticancer therapy against many neoplasms, especially ovarian cancer, testicular cancer, head and neck cancer and lung cancer $[4,5]$. It should be noted that besides the common use of cisplatin many patients develop resistance to this drug and numerous side effects occur, such as organ toxicity e.g. nephrotoxicity, reduction in the number of bone marrow cells and increased risk of deep vein thrombosis [6, 7]. Therefore, new platinum derivatives and complexes are being searched for. There are numerous studies concerning characterising platinum in trans configuration [8]. Transplatin forms 1.3 intrastrand bonds, crosslinks, equivalent to cisplatin, interstrand and monofunctional links. Trans isomer does not show any anticancer activity $[9,10]$. During recent years some reports have appeared, indicating that in a transplatin molecule a substitution of amine group with a suitable ligand increases the anticancer activity of the compound 
[11-13]. A potential synergistic effect between flavonoids and metal ions as well as some properties of trans-platinum complexes have encouraged also our team to synthesize a new platinum(II) compound with flavonoid ligand and to investigate its anticancer activity. Our studies revealed that the new trans-Pt(3-af) ${ }_{2} \mathrm{Cl}_{2}$ compound exhibits a significant cytotoxic activity towards the cells from the selected cancer cell lines, $I C_{50}$ within the rage of 4.6-16.3 $\mu \mathrm{M}$ [11]. The studied compound was only slightly less active towards neoplastic cells compared to cisplatin. What is more, it was also less toxic towards human lymphocytes than cisplatin, that is a highly demanded feature when taking into consideration the prevention of potential side effects of chemotherapy. The studied compound did not show any differences in activity towards the sensitive lines (L1210 and EJ) and the sublines resistant to cisplatin (L1210R and EJcisR) [11]. What is interesting, despite lesser cytotoxicity, the studied compound was a stronger inducer of apoptosis than cisplatin [11]. The present paper aims at characterising the antineoplastic activity of a new trans-platinum(II) complex of 3-aminoflavone towards ovarian cancer cells.

Ovarian cancer is the main cause of death in oncological gynaecology both in Poland and worldwide, what is confirmed by epidemiological data [14, 15]. In 2010 in Poland ovarian cancer was diagnosed in 3.587 women and was the cause of death of 2.547 people [15]. In 2012 approximately 239.000 of new cases of ovarian cancer and 152.000 of deaths caused by ovarian cancer were registered world wide [14]. In one of the hypotheses concerning ovarian cancer, Spencer Wells claimed that in a single layer of epithelium covering the ovary, as a result of different stimulating factors, a cancerogenesis process is initiated and it leads to cancer development [16].

Ovarian cancer is a malignant cancer showing high heterogeneity with regard to its origin, histological structure, disease course and methods of treatment. It is a cancer of epithelial origin and its ability to disseminate into the peritoneal cavity is a feature used to distinguish this carcinoma from others. In advanced stages of the disease the peritoneal cavity is the main place where metastases are formed, and it is especially observed in stage 3 and $4[17,18]$. When infiltrating the peritoneal cavity cancer cells undergo epithelial-mesenchymal transition (EMT) resulting in the loss of cadherin-E-dependent intercellular interactions. Consequently, they start to detach from the surface of the primary tumour. Cancer cells are detached from the primary tumour and captured by the peritoneal fluid. CD44 glycoprotein participates in the migration of ovarian cancer cells. Therefore, ovarian cancer cells may be from the tumour or ascites. Therefore, an important element of studies was to compare the effects of a new compound on two cell lines presenting various background with regard to the origin of ovarian cancer cells. A prognosis is also an important aspect - when the carcinoma is diagnosed late chances of cure are lower, as cancer cells become more invasive, aggressive and resistant to chemotherapy (OVCAR 3).

CA125 and CD44 integrins participate in the mechanism of metastasis formation.

In 1998 Dubean questioned the fact that all the ovarian neoplasms are derived from the epithelium covering the ovary [19]. Despite the progress in medicine and in the methods of molecular biology there is still lack of a clear hypothesis on the development of ovarian cancer [20].

Ovarian cancer is a serious diagnostic and therapeutic problem in the contemporary medicine. One of significant difficulties during the therapeutic process is the occurrence of resistance to cytotoxic treatment. In ovarian cancer chemotherapy based on several treatment regimens is applied and the chemotherapeutic agents used include: cisplatin, carboplatin, paclitaxel, etoposide, topotecan [21,22]. The studies have shown some disturbances during the course of apoptosis in ovarian cancer cells $[23,24]$. Cancer cells are characterised by the resistance to apoptosis [23]. Apoptosis is a complex process, which constitutes a programmed cell death. Both inhibition and excessive occurrence of apoptosis can become a cause of many diseases. Many proteins and genes, i.e.: $B A X$, $B C L 2, B I R C 5$ are involved in the regulation of the process of apoptosis. $B A X$ is one of the proapoptotic genes, inducing the apoptosis [25]. BCL2 inhibits the process of apoptosis [26]. BIRC5 belongs to the inhibitors of apoptosis [27].

\section{OBJECTIVES}

The aim of the present paper was to analyse the influence of trans-platinum(II) complex of 3-aminoflavone on the viability and mortality of the cells from OVCAR 3 and CAOV 3 ovarian cancer cell lines as well as the expression of the selected genes involved in the process of apoptosis.

\section{MATERIAL AND METHODS \\ Cell culture}

The studies were performed on two ovarian cancer cell lines: OVCAR 3 (ATCC HTB-161) and CAOV 3 (ATCC HTB-75) purchased at the American Type Culture Collection (ATCC) bank in the USA.

CAOV 3 is an ovarian cancer cell line with epithelial morphology. This line was established from the primary tumour of a 54-year-old female with adenocarcinoma of the ovary. Cancer cells are sensitive to vinblastine, cisplatin and adriamycin [28].

OVCAR 3 was established in 1982 by Hamilton et al. from malignant ascites of a female with progressive adenocarcinoma of the ovary. It is a cell model to study resistance to medicinal products used in the treatment of ovarian cancer. This line is resistant to cisplatin, adriamycin and melphalan. 
Thanks to these properties it is very good material for studies on new formulas, medications and compounds. OVCAR 3 includes cancer cells that are highly aggressive.The cells: OVCAR 3 and CAOV 3 show expression of CA125 [28, 29].

OVCAR 3 and CAOV 3 are both used as a cell model to study cisplatin $[30,31]$.

Cell cultures were maintained in standard conditions in Panasonic incubator (temperature: $37^{\circ} \mathrm{C}$, humidity: $5 \% \mathrm{CO}_{2}$ ); sterile Nunc cell culture vessels were used. The DMEM culture medium + GlutaMAX (Thermo Fisher Scientific, USA) was used for CAOV3 cell cultures, whereas for the OVCAR3 cells growth, the RPMI Medium 1640 (Thermo Fisher Scientific, USA) together with insulin Gensulin N (Bioton, Poland) was applied. Culture media were enriched with $10 \%$ fetal bovine serum (FBS, Lonza, USA) and AAS antibiotics (penicillin, streptomycin, amphotericin B, Sigma-Aldrich, USA). Cisplatin (Sigma-Aldrich, USA) and trans-Pt(3-af) ${ }_{2} \mathrm{Cl}_{2}$ synthesized in the Department of Bioinorganic Chemistry of the Medical University of Łódź were used in the study. The compound was synthesized as described in the publication [11]. Both cisplatin and the studied compound were dissolved in DMF(Sigma-Aldrich, USA) to the determined concentrations.

\section{The MTT assay - a spectrophotometric determination of the viability of ovarian cancer cells after treatment with a trans-platinum(II) complex of 3-aminoflavone and cisplatin}

The MTT assay relies on a colorimetric determination of a coloured product - formazan forming as a result of metabolizing of MTT, 3-(4,5-dimethylthiazol-2-yl)-2,5-diphenyltetrazolium bromide, (Sigma-Aldrich, USA) by cellular enzymes. The cells were seeded in a 24-well plate in the number of $20 \times 10^{3} /$ well in $500 \mu \mathrm{l}$ of DMEM and RPMI culture media. In the experiment the cells were incubated for 72 hours in the fresh culture media with increasing concentrations, from 5 to $100 \mu \mathrm{M}$, of trans- $\mathrm{Pt}(3-\mathrm{af})_{2} \mathrm{Cl}_{2}$ and cisplatin. After the 72-hour culture of cells with chemotherapeutic agents, the culture media were removed and $500 \mu$ l of MTT reagent $(5 \mathrm{mg} / \mathrm{mL}$ ) were added to each well; then the plate was left for incubation at $37^{\circ} \mathrm{C}$. After three hours, isopropanol ( $\mathrm{POCH}$, Poland) was added to the wells containing the cells in order to dissolve formazan crystals. The absorbance was measured at 540 and $690 \mathrm{~nm}$ using Epoch Microplate Spectrophotometer (Bio Tek, USA). All the experiments were repeated 3 times for each concentration; the arithmetic mean was considered as the final result.

\section{The LDH assay - a determination of cell death}

Cytotoxicity of the studied compounds was determined with the use of CytoSelect ${ }^{\mathrm{TM}}$ LDH Cytotoxicity Assay Kit (Cell Biolabs, USA) investigating the activity of a cytoplasmic enzyme - lactate dehydrogenase. The cells were seeded in 24-well dishes with a density of $20 \times 10^{3}$ cells/well in $500 \mu \mathrm{l}$ of DMEM and RPMI medium. After the 72-hour incubation of the cells with cytostatic agents $\left(\mathrm{IC}_{50}\right.$ : for $\mathrm{CAOV} 3$ line: cisplatin and trans-Pt(3-af) $)_{2} \mathrm{Cl}_{2}-10 \mu \mathrm{M}$; OVCAR3 line: cisplatin and trans-Pt(3-af) $\left.)_{2} \mathrm{Cl}_{2}-50 \mu \mathrm{M}\right) 90 \mu \mathrm{l}$ of the culture medium were transferred on a 96-well plate and $10 \mu \mathrm{l}$ of a reagent for the reaction catalysed by LDH were added. The plate was incubated for 3 hours at $37^{\circ} \mathrm{C}$. After the incubation the coloured product of the reaction was measured using BioTek plate reader at the wavelength of $450 \mathrm{~nm}$.

\section{RNA isolation and reverse transcription reaction}

Ovarian cancer cells from the OVCAR 3 and CAOV 3 lines were exposed to the effects of cisplatin and study compound at IC ${ }_{50}$ levels. The RNA isolation from the ovarian cancer cells was conducted according to the method of Chomczyński and Sacchi, with the use of TRIzol reagent (Thermo Fisher Scientific, USA). The purity of the obtained RNA was assessed by spectrophotometric method on Q 5000 Quawell UV-Vis spectrophotometer, measuring the absorbance at the wavelength of $260 \mathrm{~nm}$ and $280 \mathrm{~nm}$. The A260/A280 value within the range of 1.8-2.0 was the RNA purity criterion. The reverse transcription reaction was conducted with the use of High Capacity RNA-to-cDNA Kit (Thermo Fisher Scientific, USA) according to the manufacturer's protocol. After that CDNA was frozen and kept at $-20^{\circ} \mathrm{C}$ for further analyses.

\section{Real-Time PCR reaction}

The following TaqMan probes were used in the Real-Time PCR reaction: $B A X$ — Hs00180269_mL, ACTB - Hs01060665_ $\mathrm{gL}, B C L 2$ Hs 00608023-mL, BIRC5 Hs 00153353-mL (Thermo Fisher Scientific, USA). In the Real-Time PCR reaction, the obtained CDNA molecules constituted a matrix for the determination of $B A X, B C L 2, B I R C 5$ gene expression. The reaction mixture constituted of: $0.5 \mu$ l of TaqMan Gene Expression Assay probe (Thermo Fisher Scientific, USA), $5 \mu$ l of TaqMan Gene Expression Master Mix (Thermo Fisher Scientific, USA), $2.5 \mu \mathrm{l}$ of water and $50 \mathrm{ng}$ of cDNA per well. The Real-Time PCR reaction was conducted in ViiA7 instrument (Thermo Fisher Scientific, USA). The obtained gene expression results were compared with the reference gene $A C T B$. Relative gene expression level was calculated with the use of $2^{-\Delta \Delta} C T$ method.

\section{Statistical analysis}

The statistical analysis was conducted using GraphPAD Prism 6 computer program by GraphPad Software Inc. The results of the experiments were analysed by Bonferroni test in order to determine the statistically significant differences between the control groups and the studied compounds. The differences were considered statistically significant at the confidence level below 0.05 ( $^{*} \mathrm{p}<0.05$; ** $\mathrm{p}<0.01$; $\left.^{* * *} \mathrm{p}<0.001,{ }^{* * *} \mathrm{p}<0.0001\right)$. 

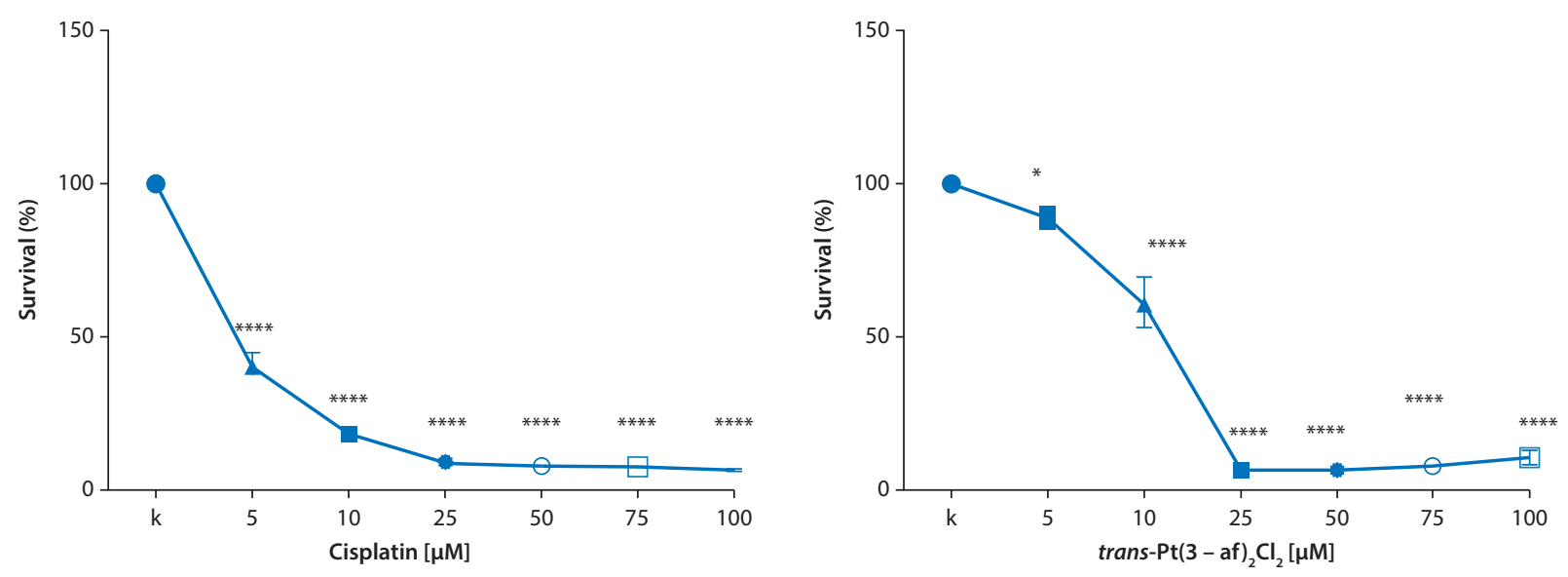

Figure 1. The viability of the cells from CAOV 3 ovarian cancer cell line after the 72-hour incubation with cisplatin and trans- $\mathrm{Pt}(3-\mathrm{af})_{2} \mathrm{Cl}_{2}$. Three independent experiments in three repeats were performed. The mean values marked as $*(p<0.05)$, ${ }^{* * *}(p<0.0001)$ are statistically significantly different from controls
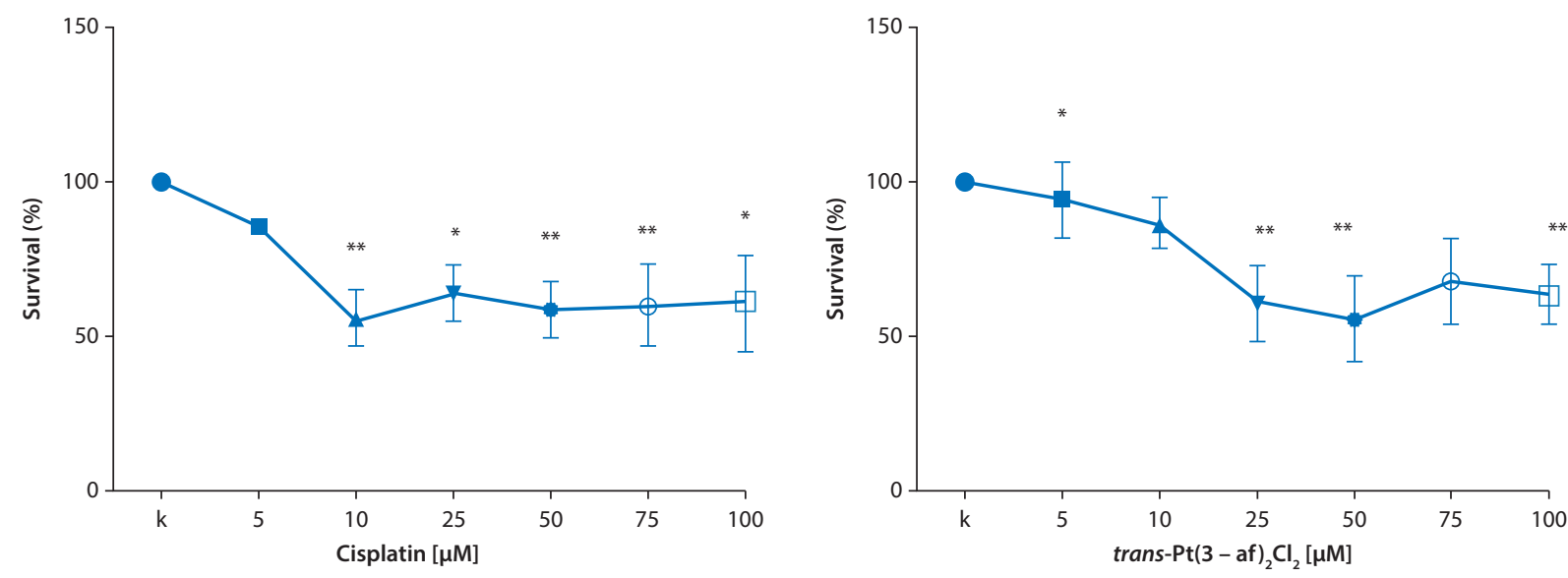

Figure 2. The viability of the cells from OVCAR 3 ovarian cancer cell line after the 72 -hour incubation with cisplatin and trans- $\mathrm{Pt}(3 \text {-af })_{2} \mathrm{Cl}_{2}$. Three independent experiments in three repeats were performed. The mean values marked as $*(p<0.05),{ }^{* *}(p<0.01)$ are statistically significantly different from controls

\section{RESULTS}

The viability assessment of ovarian cancer cells of ascites and tumour cell lines after the exposure to the trans-platinum(II) complex of 3-aminoflavone and cisplatin

The MTT assay was applied in order to assess the influence of the studied compound and cisplatin on ovarian cancer cells from OVCAR 3 and CAOV 3. The studies have demonstrated that together with the increase in the concentrations within the range of 5-100 $\mu \mathrm{M}$, there is a decrease in viability of the CAOV 3 (Fig. 1) and OVCAR 3 (Fig. 2) cancer cell lines. Some experiments on reference compounds (3-aminoflavone, transplatin) were also carried out. The results of the MTT assay are shown in Figure 3.

The cytotoxicity assessment of the studied compounds by the LDH method (Fig. 4).

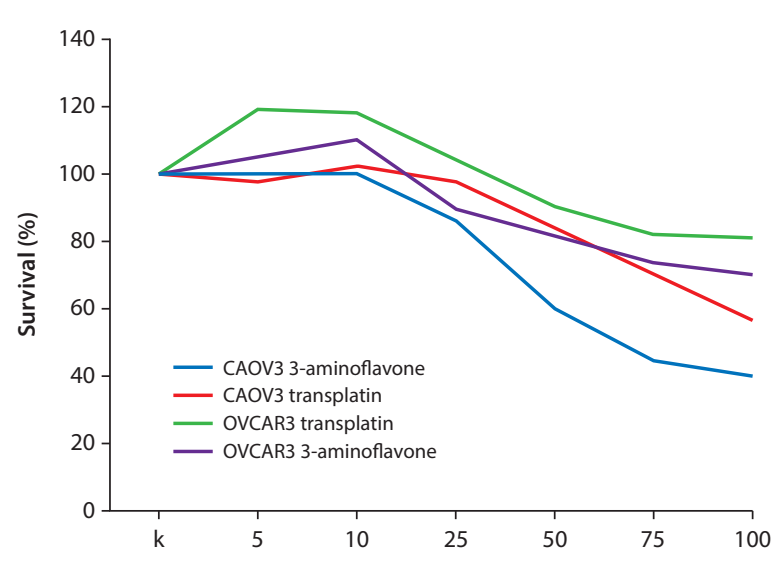

Figure 3. The MTT assay results determining the anticancer activity of 3-aminoflavone and transplatin in CAOV 3 and OVCAR 3 cell lines after the 72-hour incubation 


\section{The effect of trans-Pt(3-af) ${ }_{2} \mathrm{Cl}_{2}$ and cisplatin on $B A X, B C L 2, B I R C 5$ gene expression}

$B A X, B C L 2, B I R C 5$ gene expression on the mRNA level was analysed in the cells from OVCAR 3 and CAOV 3 ovarian cancer cell lines after the exposure to trans- $\mathrm{Pt}(3-\mathrm{af})_{2} \mathrm{Cl}_{2}$ and cisplatin in the concentration of $\mathrm{IC}_{50}$, during 72 hours. Cells that were not treated with the studied compounds served as controls. The studies have shown an increase in $B A X$ gene expression, and a decrease in BCL2 and BIRC5 gene expression (Fig. 5-7).

\section{DISCUSSION}

A combination of chemotherapy based on platinum derivatives is routinely used in patients after cytoreductive surgery, but only approximately $70-80 \%$ of patients with ovarian cancer respond positively to chemotherapy [32].

Moreover, drug resistance that occurs in patients decreases cell sensitivity to chemotherapy, causes disease recurrence and contributes to metastasis formation. These result in a worse prognosis. Therefore, it is very important to get to know the mechanisms that determine drug resistance. However, it is cisplatin that, despite the numerous side effects, is the most often used chemotherapeutic agent [33]. Ineffective apoptosis can be the cause of chemoresistance of cancer cells [34].

In the search for new drugs, in recent years there has been a significant interest in trans-platinum compounds. Transplatin is less toxic for tumour cells than cisplatin [35]. The cytotoxicity of trans-platinum complexes with ligands is higher [11].

The platinum(II) compound with 3-aminoflavone was synthesized in the Department of Bioinorganic Chemistry of the Medical University of Łódź. The results of the studies presented in this paper indicate that the new compound exhibits anticancer properties against ovarian cancer cells. In the studies molecular biology methods were applied — the in vitro assessment of the proapoptotic activity of the studied compound. In ovarian cancer disturbances in the process

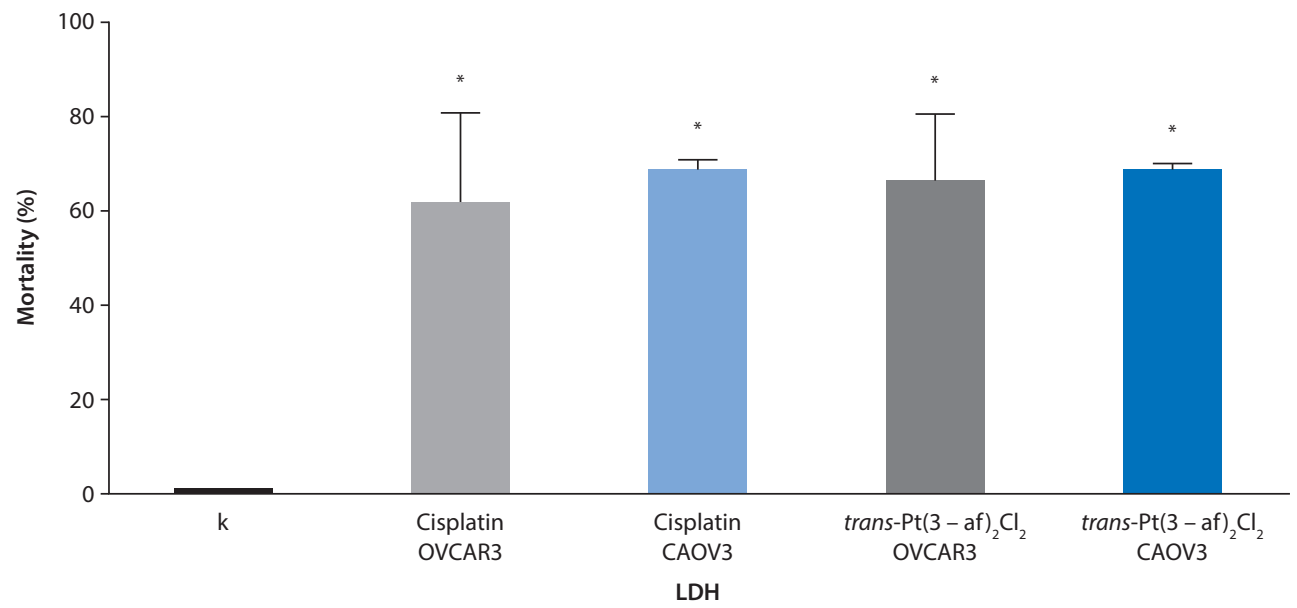

Figure 4. The cytotoxic effect of the studied compound and cisplatin on the cells from OVCAR 3 and CAOV 3 cell lines assessed using the LDH assay. The mean values marked as* $(p<0.05)$ are statistically significantly different from controls
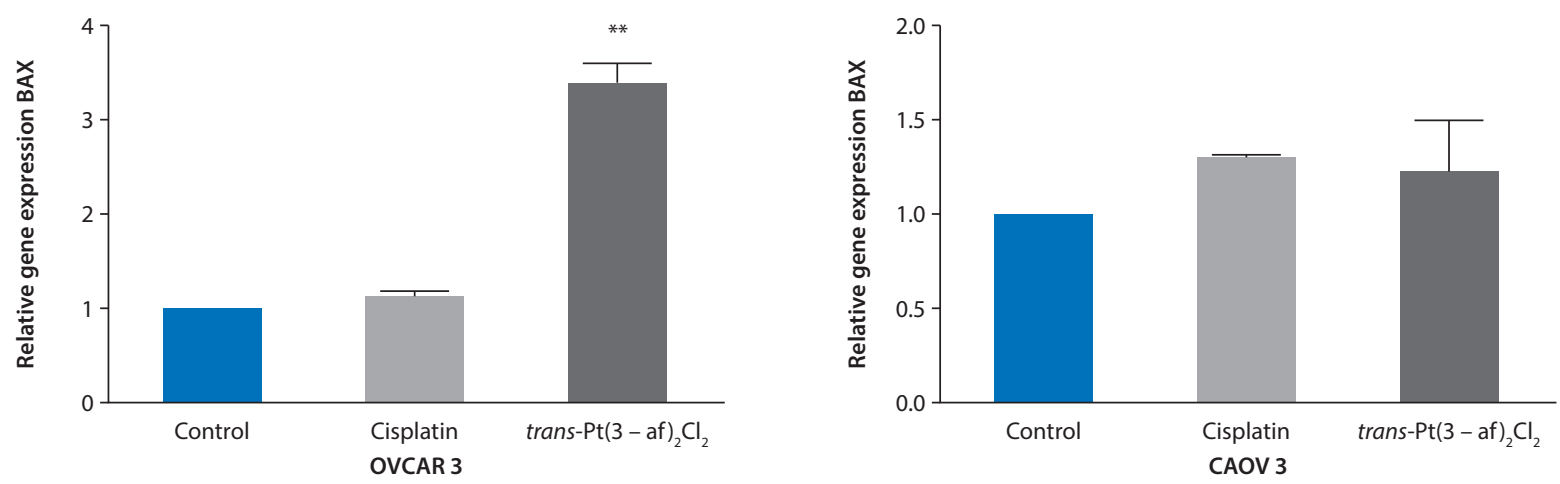

Figure 5. BAX gene expression in OVCAR 3 and CAOV 3 ovarian cancer cells treated with cisplatin and trans- $\mathrm{Pt}(3-\mathrm{af})_{2} \mathrm{Cl}{ }_{2}$. The gene expression level was expressed as relative values compared to the control that equals 1 . The mean values marked as $*^{*}(p<0.01)$ are statistically significantly different from controls 

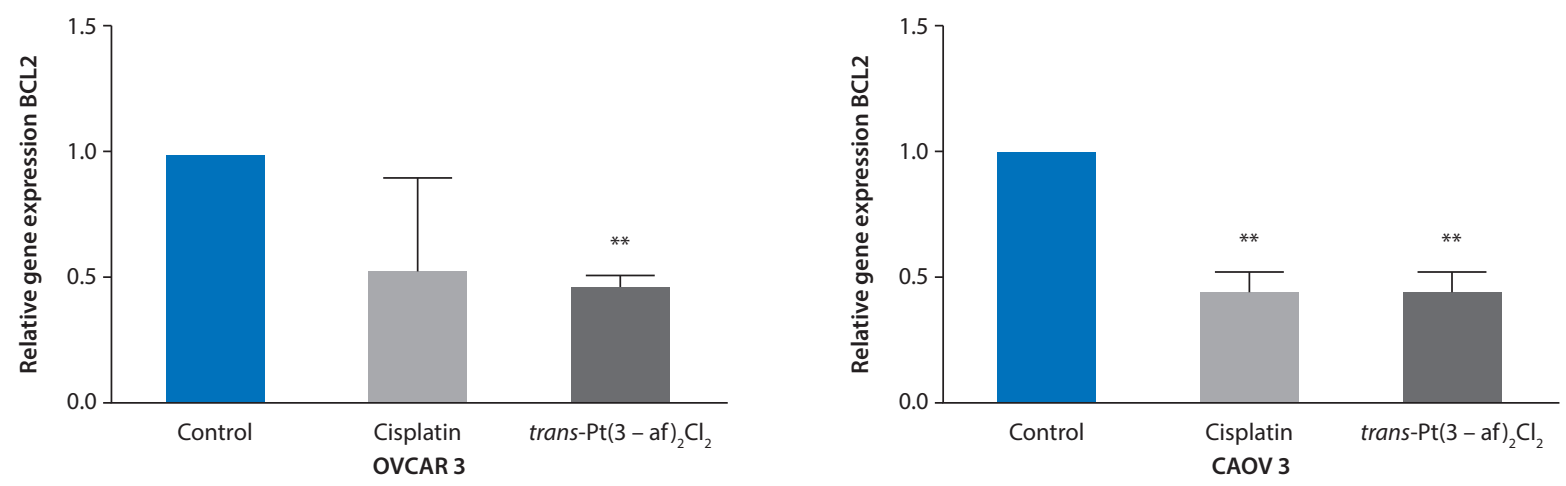

Figure 6. $B C L 2$ gene expression in OVCAR 3 and CAOV 3 ovarian cancer cells treated with cisplatin and trans- $\mathrm{Pt}(3-\mathrm{af})_{2} \mathrm{Cl} \mathrm{I}_{2}$. The gene expression level was expressed as relative values compared to the control that equals 1 . The mean values marked as $*(p<0.05)$ are statistically significantly different from controls
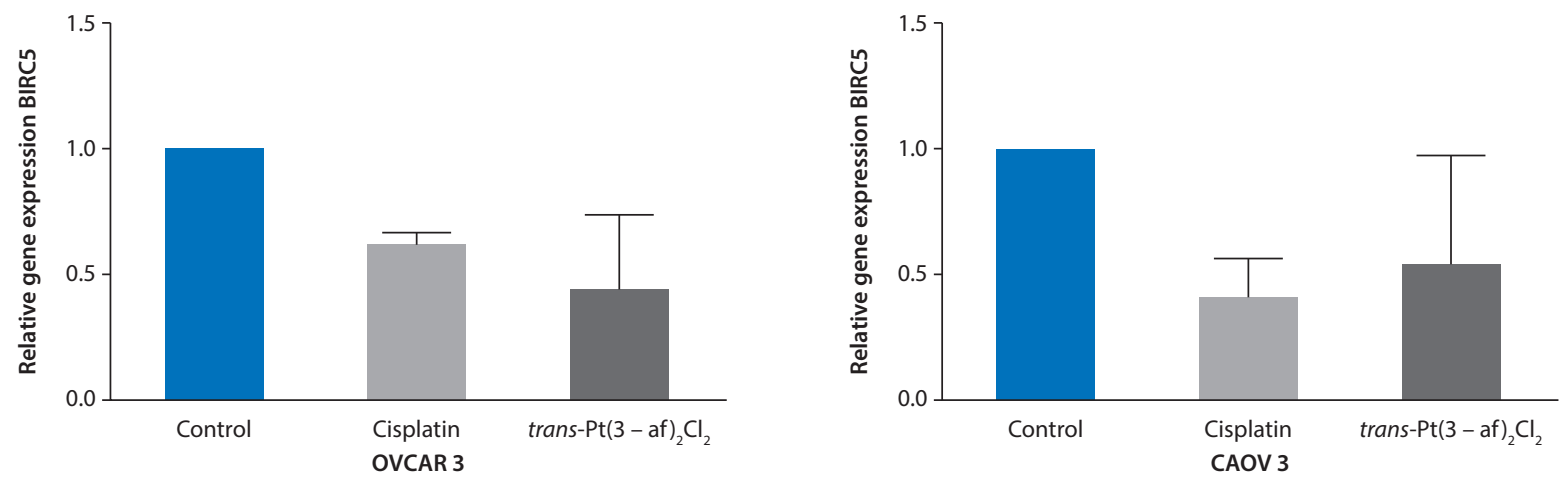

Figure 7. BIRC5 gene expression in OVCAR 3 and CAOV 3 ovarian cancer cells treated with cisplatin and trans-Pt( 3 -af $)_{2} \mathrm{Cl}{ }_{2}$. The gene expression level was expressed as relative values compared to the control that equals 1

of apoptosis are observed. That is why our aim was to analyse the effect of both cisplatin and the compound on the expression of key genes associated with apoptosis.

In the present paper it was demonstrated that both cisplatin and the studied compound with increasing dose values decrease the viability of ovarian cancer cells. The obtained results concerning cisplatin are consistent with the available data in the literature $[36,37]$. Smith et al. treated CAOV 3 and OVCAR 3 ovarian cancer cells with cisplatin and demonstrated the decrease in cell viability [36]. Thomadaki et al. also showed that after the administration of cisplatin to the cells, a decrease in viability occurs [37]. In the presented study the analysis of cisplatin effect on the expression of genes involved in the process of apoptosis showed that the studied drug causes an increase in $B A X$ gene expression.

The studies demonstrated that after the exposure to cisplatin, the BCL2 gene activity is characterised by a decrease in the expression compared to the non-treated ovarian cancer cells. Ding et al. treated the cells from SKOV 3 ovarian cancer cell line with cisplatin and showed a decrease in $B C L 2$ gene expression [38]. The studied newly-synthesized compound trans-Pt(II) with 3-aminoflavone showed, similarly to cisplatin, an increase in BAX gene expression. Identical result was obtained when cis-Pt(II) with 3-aminoflavone was studied [39]. The compound causes a decrease in the expression of $B C L$ antiapoptotic gene. In the present paper it is also indicated that after the exposure of ovarian cancer cells to the studied compound and cisplatin, a decrease in the survivin gene expression occurs. Lesan et al. investigated the effect of metformin and cisplatin on gastric cancer cells and have also demonstrated a decrease in the survivin gene expression in cells [40]. Moreover, Wang et al. also showed that after the treatment of ovarian cancer cells with cisplatin, a decrease in the survivin gene expression occurs [41]. The conducted analyses are the first studies on the effect of the new platinum(II) compound on ovarian cancer cell lines. The results of our studies indicate that trans- $\mathrm{Pt}(3-\mathrm{af})_{2} \mathrm{Cl}_{2}$ exhibits anticancer properties on the level comparable to cisplatin - a classical drug, routinely used in clinical departments.

\section{CONCLUSIONS}

A trans-platinum(II) complex of 3-aminoflavone decreases the viability of ovarian cancer cells in the doses compa- 
rable to cisplatin. It was demonstrated that this compound induces the expression of proapoptotic gene $B A X$.

\section{ACKNOWLEDGEMENTS}

This work was supported partly by the National Science Centre grant No. NN 405674040 and the Medical University of Lodz grant statute 503/3-016-02/503-01.

\section{REFERENCES}

1. Rosenberg B, Vancamp L, Krigas T. Inhibition of cell division in Escherichia coli by electrolysis products from a platinum electrode. Nature. 1965; 205: 698-699, indexed in Pubmed: 14287410.

2. Pinto AL, Lippard SJ. Binding of the antitumor drug cis-diamminedichl oroplatinum(II) (cisplatin) to DNA. Biochim Biophys Acta. 1985; 780(3): 167-180, indexed in Pubmed: 3896310.

3. Gonzalez VM, Fuertes MA, Alonso C, et al. Is cisplatin-induced cell death always produced by apoptosis? Mol Pharmacol. 2001; 59(4): 657-663, indexed in Pubmed: 11259608.

4. Helm CW, States JC. Enhancing the efficacy of cisplatin in ovarian cancer treatment - could arsenic have a role. J Ovarian Res. 2009; 2: 2, doi: 10.1186/1757-2215-2-2, indexed in Pubmed: 19144189.

5. Subocz M, Popławska B, Bielawska A, et al. Pochodne platyny w chemioterapii chorób nowotworowych. Ann. Acad. Med. Siles. 2011, 65; 4: 70-76.

6. Dudziak J, Słomczyński M, Torliński L. Powikłania kardiologiczne po chemioterapii- patomechanizm, diagnostyka, leczenie i zapobieganie .Choroby Serca i Naczyń. 2009, 6. ; 2: 73-81.

7. Johnson N, Butour JL, Villani G, et al. Metal Antitumor Compounds: The Mechanism of Action of Platinum Complexes. Progress in Clinical Biochemistry and Medicine. 1989: 1-24, doi:10.1007/978-3-642-74760-1 1.

8. Fanelli M, Formica M, Fusi V, et al. New trends in platinum and palladium complexes as antineoplastic agents. Coordination Chemistry Reviews. 2016; 310: 41-79, doi: 10.1016/j.ccr.2015.11.004.

9. Trynda-Lemiesz L, Śliwińska-Hill U. Kompleksy metali w terapii nowotworowej. Teraźniejszość i przyszłość NOWOTWORY Journal of Oncology. 2011, 61. ; 5: 465-474.

10. Aris SM, Farrell NP. Towards Antitumor Active trans-Platinum Compounds. Eur J Inorg Chem. 2009; 2009(10): 1293, doi: 10.1002/ejic.200801118, indexed in Pubmed: 20161688.

11. Fabijańska M, Studzian K, Szmigiero L, et al. trans-Platinum(II) complex of 3-aminoflavone - synthesis, X-ray crystal structure and biological activities in vitro. Dalton Trans. 2015; 44(3): 938-947, doi: 10.1039/c4dt01501k, indexed in Pubmed: 25110914.

12. Matlawska-Wasowska K, Rainczuk K, Kalinowska-Lis U, et al. Genotoxicity of novel trans-platinum(II) complex with diethyl (pyridin-4-ylmethyl) phosphate in human non-small cell lung cancer cells A549. Chem Biol Interact. 2007; 168(2): 135-142, doi: 10.1016/j.cbi.2007.04.001, indexed in Pubmed: 17499650.

13. Herrera JM, Mendes F, Gama S, et al. Design and biological evaluation of new platinum(II) complexes bearing ligands with DNA-targeting ability. Inorg Chem. 2014; 53(23): 12627-12634, doi: 10.1021/ic502373n, indexed in Pubmed: 25402634.

14. Krajowa Baza Danych Nowotworowych - Zakład Epidemiologii i Prewencji Nowotworów Centrum Onkologii. : Warszawa.

15. http://globocan.iarc.fr/Default.aspx.

16. Nowak-MarkwitzE, Spaczyński M. Ovarian cancer--modern approach to its origin and histogenesis. Ginekol Pol. 2012; 83(6): 454-457, indexed in Pubmed: 22880466.

17. Lengyel E. Ovarian cancer development and metastasis. Am J Pathol. 2010; 177(3): 1053-1064, doi: 10.2353/ajpath.2010.100105, indexed in Pubmed: 20651229.

18. Desjardins $M, X i e ~ J, G u r l e r ~ H$, et al. Versican regulates metastasis of epithelial ovarian carcinoma cells and spheroids. J Ovarian Res. 2014; 7: 70, doi: 10.1186/1757-2215-7-70, indexed in Pubmed: 24999371.

19. Dubeau $L$. The cell of origin of ovarian epithelial tumors and the ovarian surface epithelium dogma: does the emperor have no clothes? Gynecol Oncol. 1999; 72(3): 437-442, doi: 10.1006/gyno.1998.5275, indexed in Pubmed: 10053122.
20. Kujawa KA, Lisowska KM. Ovarian cancer--from biology to clinic. Postepy Hig Med Dosw (Online). 2015; 69: 1275-1290, indexed in Pubmed: 26671919.

21. Brigulová $K$, Cervinka M, Tošner J, et al. Chemoresistance testing of human ovarian cancer cells and its in vitro model. Toxicol In Vitro. 2010; 24(8): 2108-2115, doi: 10.1016/j.tiv.2010.08.010, indexed in Pubmed: 20736059.

22. de Bree E, Theodoropoulos PA, Rosing H, et al. Treatment of ovarian cancer using intraperitoneal chemotherapy with taxanes: from laboratory bench to bedside. Cancer Treat Rev. 2006; 32(6): 471-482, doi: 10.1016/j. ctrv.2006.07.006, indexed in Pubmed: 16942841.

23. Hanahan D, Weinberg RA. Hallmarks of cancer: the next generation. Cell. 2011; 144(5): 646-674, doi: 10.1016/j.cell.2011.02.013, indexed in Pubmed: 21376230.

24. Szala S. Swoista indukcja apoptozy w komórkach nowotworowych. NOWOTWORY. 2000, 50. ; 2: 111-121.

25. Rzońca S, Małecki M. Proapoptotyczna terapia genowa a wrażliwość nowotworów na chemioterapię. Współczesna Onkol. 2009; 13: 61-65.

26. Ealovega MW, McGinnis PK, Sumantran VN, et al. bcl-xs gene therapy induces apoptosis of human mammary tumors in nude mice. Cancer Res. 1996; 56(9): 1965-1969, indexed in Pubmed: 8616832.

27. Holcik M. The IAP proteins. Trends in Genetics. 2002; 18(10): 537-538, doi: 10.1016/s0168-9525(02)02743-9.

28. www.mskcc.org/research-advantage/support/technology/tangible-material/caov-3-human-ovarian-cell-line.

29. Kloudová K, Hromádková H, Partlová S, et al. Expression of tumor antigens on primary ovarian cancer cells compared to established ovarian cancer cell lines. Oncotarget. 2016; 7(29): 46120-46126, doi: 10.18632/oncotarget.10028, indexed in Pubmed: 27323861.

30. Gibb RK, Taylor DD, Wan T, et al. Apoptosis as a measure of chemosensitivity to cisplatin and taxol therapy in ovarian cancer cell lines. Gynecol Oncol. 1997; 65(1): 13-22, indexed in Pubmed: 9103385.

31. Hamilton TC, Young RC, McKoy WM, et al. Characterization of a human ovarian carcinoma cell line (NIH:OVCAR-3) with androgen and estrogen receptors. Cancer Res. 1983; 43(11): 5379-5389, indexed in Pubmed: 6604576.

32. Wcisło G. High-dose chemotherapy of ovarian cancer followed by bone marrow transplantation or peripheral blood stem cell support. Współczesna Onkol. 2005, 9. ; 1: 14-22.

33. van Haaften $C$, Boot $A$, Corver WE, et al. Synergistic effects of the sesquiterpene lactone, EPD, with cisplatin and paclitaxel in ovarian cancer cells. J Exp Clin Cancer Res. 2015:34-38, doi: 10.1186/s13046-015-0157-2, indexed in Pubmed: 25907439.

34. Pommier $Y$, Sordet $O$, Antony $S$, et al. Apoptosis defects and chemotherapy resistance: molecular interaction maps and networks. Oncogene. 2004; 23(16): 2934-2949, doi: 10.1038/sj.onc.1207515, indexed in Pubmed: 15077155.

35. Natile G, Coluccia M. Current status of trans-platinum compounds in cancer therapy. Coordination Chemistry Reviews. 2001; 216-217: 383-410, doi: 10.1016/s0010-8545(01)00315-0.

36. Smith JA, Ngo H, Martin MC, et al. An evaluation of cytotoxicity of the taxane and platinum agents combination treatment in a panel of human ovarian carcinoma cell lines. Gynecol Oncol. 2005; 98(1): 141-145, doi: 10.1016/j.ygyno.2005.02.006, indexed in Pubmed: 15963813.

37. Thomadaki $\mathrm{H}$, Scorilas A. Molecular profile of breast versus ovarian cancer cells in response to treatment with the anticancer drugs cisplatin, carboplatin, doxorubicin, etoposide and taxol. Biol Chem. 2008; 389(11): 1427-1434, doi: 10.1515/BC.2008.161, indexed in Pubmed: 18783338.

38. Ding $L$, Wang $X Q$, Zhang J, et al. Underlying mechanism of 2-methoxyestradiol-induced apoptosis and growth arrest in SKOV3 human ovarian cancer cells. Eur Rev Med Pharmacol Sci. 2015; 19(11): 2084-2090, indexed in Pubmed: 26125273.

39. Kosmider B, Wojcik I, Osiecka R, et al. Enhanced P53 and BAX gene expression and apoptosis in A549 cells by cis-Pt(II) complex of 3-aminoflavone in comparison with cis-DDP. Invest New Drugs. 2005; 23(4): 287-297, doi: 10.1007/s10637-005-1437-z, indexed in Pubmed: 16012788.

40. Lesan V, Ghaffari SH, Salaramoli J, et al. Evaluation of antagonistic effects of metformin with Cisplatin in gastric cancer cells. Int J Hematol Oncol Stem Cell Res. 2014; 8(3): 12-19, indexed in Pubmed: 25642303.

41. Wang $Z$, Xie $Y$, Wang $H$. Changes in survivin messenger RNA level during chemotherapy treatment in ovarian cancer cells. Cancer Biology \& Therapy. 2014; 4(7): 716-719, doi: 10.4161/cbt.4.7.1782. 